The Journal of Animal \& Plant Sciences, 30(5): 2020, Page: 1115-1122

ISSN (print): 1018-7081; ISSN (online): 2309-8694

\title{
MICROSATELLITE BASED GENETIC DIVERSITY IN INDIGENOUS GOAT BREEDS REARED IN ALGERIA AND TURKEY
}

\author{
H. Tefiel ${ }^{* 1}$, N. Ata ${ }^{2}$, K. Fantazi ${ }^{3}$, O. Yilmaz ${ }^{2}$, I. Cemal ${ }^{2}$, O. Karaca², M. Chahbar ${ }^{1}$, A. Ameur Ameur ${ }^{4}$ and \\ S. B. S. Gaouar ${ }^{4}$
}

\begin{abstract}
${ }^{1}$ Agronomy Environment Laboratory, Department of Natural Sciences and Life, Institute of Science and Technology, University Center Ahmed Benyahia El Wancharissi, Tissemsilt, Algeria. ${ }^{2}$ Department of Animal Science, Faculty of Agriculture, Adnan Menderes University, Aydın, Turkey; ${ }^{3}$ National Institute of Agronomic Research, Animal Productions Division, INRA Algeria, BP200 Hassen Badi, El-Harrach 16200, Algiers, Algeria;

${ }^{4}$ PpBioNut Laboratory, University Abou Bekr Bélkaid, Tlemcen, Algeria.

*Corresponding author’s email: hakimtefiel@yahoo.fr, tefiel.hakim@cuniv-tissemsilt.dz
\end{abstract}

\begin{abstract}
In the present study, the relationship between some indigenous goat breeds from Algeria (Arbia (AR), Mekatia (ME), Naine de Kabylie (NK) and M'zabite (MO)) and Turkey (Hair goat (HG) and Damascus (DA)) was investigated with 18 microsatellites markers recommended by FAO (2011). Three multiplex groups were formed according to fragment length of microsatellites. Polymerase chain reaction (PCR) amplifications were carried out in $25-\mu \mathrm{L}$ total volumes. Touchdown PCR protocols was used for amplification of specific genomic regions. Capillary electrophoresis was used for the separation of the PCR fragments labeled with fluorescent dye in the Beckman Coulter GeXP genetic analyzer. PIC, $F_{\text {IS }}, F_{\text {IT }}$ and $\mathrm{F}_{\mathrm{ST}}$ values were $0.93,0.083,0.146$ and 0.069 , respectively. The Ho and He values estimated as 0.81 and 0.93 , respectively. The MNA across the breeds ranged from 12.78 in the MO to 15.72 in the AR breed. The Ho ranged from 0.77 (DA breed) to 0.88 (NK breed). The He is lowest in HG breed (0.84) and highest in NK breed (0.90). All breeds showed positive $\mathrm{F}_{\mathrm{IS}}$ values. The private alleles observed in the studied goat breeds were highest (33) in the DA breed, with a total of 117 private alleles. However, only 58 of them had a frequency higher than $5 \%$. As a result, the dendrogram shows that the Algerian goat breeds were completely separated from the Turkish goat breed. On the other hand, $\Delta \mathrm{K}$ value indicated that the most suitable group number was $3(\mathrm{~K}=3)$. Further studies are recommended considering goats from other Mediterranean countries.
\end{abstract}

Key words: Genetic diversity, Algerian goat breeds, Turkish goat breeds, microsatellites, population genetic structure.

https://doi.org/10.36899/JAPS.2020.5.0127

Published online June 25, 2020

\section{INTRODUCTION}

In recent years, goat breeding has become an important livestock activity that stands out economically all over the world (Darcan and Silanikove, 2018). The origin of domestic goats remain ambiguous and controversial issue, but archaeological findings probably indicate that they were domesticated 10000 years ago in the Fertile Crescent region covering Palestine, Turkey, Lebanon, Jordan, and Syria (Zeder and Hesse, 2000; Luikart et al., 2001; Taberlet et al., 2011; Amills et al., 2017). Goat breeding in Turkey that has an important traditional background plays an important role in meeting the animal protein deficit by evaluating areas that other farm animals cannot use (Gursoy, 2006). During the Ottoman Empire, the goats of the Fertile Crescent were moving up in Europe, Asia and Africa (Porter, 2002). Furthermore, there has always been smuggling of animals, essentially goats and sheep, from Turkey to the Maghreb region and especially Algerian territory during the guardianship of the Ottoman's Empire.
Goats are an integral part of rural livelihood and contribute significantly to food security and poverty alleviation among poor and marginal farmers in many developing economies. In human history, Arab people have been linked to the intercontinental trade of goods, plants and animals across Africa, Europe and Asia. Due to their activity as important traders, Arabs were frequent travelers and also experienced massive demographic movements. These movements displaced both people and their animals across the Mediterranean region (Martin, 1974). Canon et al., (2006) have signaled the importance of the Mediterranean Sea as a channel for the circulation of humans and animals in a continuous network of trade and commercial exchange. The goat population in Turkey is around 10.5 million head according to FAO data (FAO, 2016). Although, Hair goat population constitutes about $90 \%$ of total goat population in Turkey, it is possible to mention many different goat genotypes such as Hair, Norduz, Angora, Honamli, Abaza, Shami, Hatay and Kilis breeds that have been well adapted to different regions (Keskin and Biçer, 1997; Keskin, 2000; Yilmaz et al., 2012). 
The relationship between Turkish and Algerian breeds has not been previously analyzed. Studies with microsatellite markers in Turkish goat breeds (Agaoglu and Ertugrul, 2012, Gurler and Bozkaya 2013) have shown a high genetic variability within and between goat breeds. The Algerian goats included animals from a large population, previously studied phenotypically (Fantazi et al., 2017, Belantar et al., 2018) and genetically (Tefiel et al., 2018) to characterize and identify a possible geographical subdivision. The results showed that the four Algerian native goat breeds are classified into distinct breeds with a good level of genetic diversity. But the most of these studies focused on diversity and relationships of goat breeds at country level while very little information is available at regional level. Investigation of molecular genetic diversity is a valuable complement to evaluate phenotypes and production systems. It provides insights into breed history, guides breed development and helps in conservation decision making (Ajmone-Marsan et al., 2014). The first step for a well-structured and sustainable animal breeding and conservation program is to reveal detailed information on intra and inter-breed genetic diversity. This situation indicates how important it is to reveal the genetic structure of breeds. The goal of the present study was to investigate the genetic diversity, population structure and genetic relationships between 4 Algerian and 2 Turkish goat breeds, based on their geographical proximity, historical influence, and their current relevance using 18 microsatellites markers.

\section{MATERIALS AND METHODS}

Samples and DNA extraction: A total of 320 samples belonging to Algerian and Turkish goat breeds were collected from unrelated animals (Table 1). Blood samples were collected from the jugular veins of the animal using vacutainer tube containing K3EDTA. DNA was extracted by using salting-out technique reported by Miller et al. (1988) and Montgomery and Sise (1990). NanoDrop 2000 (Thermo Scientific, Waltham, MA) spectrophotometer device was used to determinate quality and quantity of DNA samples.

Table 1. Sampling information of Algerian and Turkish goat breeds.

\begin{tabular}{lllll}
\hline Country & $\begin{array}{l}\text { Breed's } \\
\text { name }\end{array}$ & Abreviation & Location & N \\
\hline \multirow{4}{*}{ Algeria } & Arbia & AR & $\begin{array}{l}\text { Djelfa, } \\
\text { Tissemsilt }\end{array}$ & 50 \\
& Mekatia & ME & Laghouat & 50 \\
& $\begin{array}{l}\text { Naine de } \\
\text { Kabylie }\end{array}$ & NK & Bejaïa & 50 \\
& M'zabite & MO & Ghardaïa & 30 \\
\hline \multirow{2}{*}{ Turkey } & Hair goat & HG & Aydın, Denizli & 100 \\
& Damascus & DA & Gaziantep & 40 \\
\hline N : number of samples & & Total & $\mathbf{3 2 0}$ \\
\cline { 3 - 5 }
\end{tabular}

PCR and fragment analysis: To generate data, a microsatellite set of 18 markers were selected based on the guidelines of FAO (2011). Three multiplex groups were formed according to fragment length of microsatellites. Polymerase chain reaction (PCR) amplifications were carried out in $25-\mu \mathrm{L}$ total volumes, containing $0.20 \mathrm{mM}$ dNTPs, $0.10 \mu \mathrm{M}$ of primers (forward and reverse), $2.0 \mathrm{mM} \mathrm{MgCl}_{2}, 1 \mathrm{X}$ PCR buffer, $1 \mathrm{U}$ of Taq DNA polymerase, and $\sim 50 \mathrm{ng}$ of DNA.

Touchdown PCR protocols was used for amplification of specific genomic regions (Table 2). Capillary electrophoresis was used for the separation of the PCR fragments labeled with fluorescent dye in the Beckman Coulter GeXP genetic analyzer (Beckman Coulter, Inc., USA). Genome Lab ${ }^{\mathrm{TM}}$ DNA Size Standard Kit 400 was used for the determination of the fragment sizes.

Table 2. Touchdown PCR protocol used in the study.

\begin{tabular}{|c|c|c|c|c|c|c|c|}
\hline $\begin{array}{l}\text { Multiplex } \\
\text { Group }\end{array}$ & Microsatellites & $\begin{array}{c}\text { First } \\
\text { Denaturation }\end{array}$ & Denaturation & Annealing & Extension & Cycle & $\begin{array}{c}\text { Final } \\
\text { Extension }\end{array}$ \\
\hline M1 & $\begin{array}{l}\text { INRA0023 } \\
\text { INRA0005 } \\
\text { OarFCB20 } \\
\text { ILST0019 } \\
\text { BM1818 } \\
\text { INRA0132 }\end{array}$ & $\begin{array}{c}95^{\circ} \mathrm{C} \\
(5 \mathrm{~min})\end{array}$ & $\begin{array}{c}95^{\circ} \mathrm{C} \\
(40 \mathrm{sec})\end{array}$ & $\begin{array}{c}60-50{ }^{\circ} \mathrm{C} \\
(40 \mathrm{sec})\end{array}$ & $\begin{array}{c}72^{\circ} \mathrm{C} \\
(1 \mathrm{~min})\end{array}$ & 30 & $\begin{array}{c}72^{\circ} \mathrm{C} \\
(10 \mathrm{~min})\end{array}$ \\
\hline M2 & $\begin{array}{l}\text { CSRD0247 } \\
\text { McM0527 } \\
\text { SRCRSP0005 } \\
\text { ILSTS0087 } \\
\text { SRCRSP0023 } \\
\text { HSC (OLADRB) } \\
\text { BM1329 }\end{array}$ & $\begin{array}{c}95^{\circ} \mathrm{C} \\
(5 \mathrm{~min})\end{array}$ & $\begin{array}{c}95^{\circ} \mathrm{C} \\
(40 \mathrm{sec})\end{array}$ & $\begin{array}{c}60-50{ }^{\circ} \mathrm{C} \\
(40 \mathrm{sec})\end{array}$ & $\begin{array}{c}72^{\circ} \mathrm{C} \\
(1 \mathrm{~min})\end{array}$ & 30 & $\begin{array}{c}72^{\circ} \mathrm{C} \\
(10 \mathrm{~min})\end{array}$ \\
\hline M3 & INRA063 & $95^{\circ} \mathrm{C}$ & $95^{\circ} \mathrm{C}$ & $63-50{ }^{\circ} \mathrm{C}$ & $72^{\circ} \mathrm{C}$ & 30 & $72^{\circ} \mathrm{C}$ \\
\hline
\end{tabular}




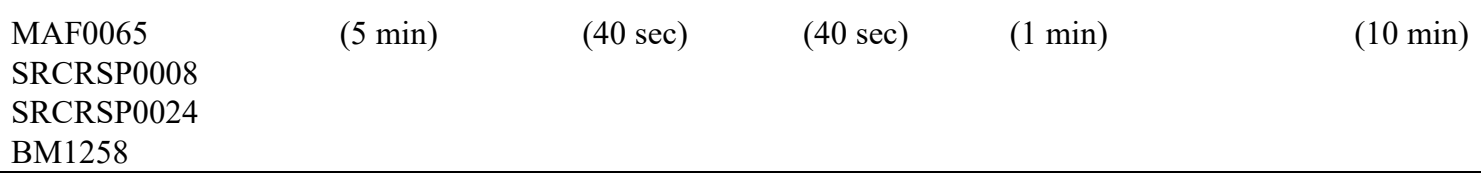

Statistical Analysis: The polymorphism statistics such as number of alleles per locus $(\mathrm{Na})$, mean number of alleles $(\mathrm{MNa})$, effective number of alleles $(\mathrm{Ne})$, observed heterozygosity (Ho), expected heterozygosity $(\mathrm{He})$ and Hardy-Weinberg equilibrium were calculated using GenAlEx (Peakall and Smouse, 2006, 2012). Polymorphic information content (PIC) and null allele frequencies were calculated using CERVUS 3.0.3 (Marshall, 1998; Kalinowski et al., 2007), while Wright's F-statistics coefficients ( $\left.\mathrm{F}_{\text {IT }}, \mathrm{F}_{\mathrm{IS}}, \mathrm{F}_{\mathrm{ST}}\right)$ (Weir and Cockerham, 1984; Wright, 1931) were obtained with GENEPOP version 4.0.10 (Raymond and Rousset, 2011). Population 1.2.32 (Langella, 1999) and FigTree 1.4.2. (Rambout, 2015) software were used to generate phylogenetic tree between breeds according to Nei's Da distance matrix (Nei et al., 1983). Robustness of the dendrogram topology was tested by bootstrap resampling $(\mathrm{n}=1000)$. FSTAT version 2.9.3 software (Goudet, 2001) was used to obtain values belong to genetic diversity statistics such as Nei's gene diversity $\left(\mathrm{H}_{\mathrm{T}}\right)$, diversity between breeds $\left(\mathrm{D}_{\mathrm{ST}}\right)$, and coefficient of gene differentiation $\left(\mathrm{G}_{\mathrm{ST}}\right)$. Analysis of molecular variance (AMOVA), which is a method to detect population differentiation utilizing molecular markers, was performed using the ARLEQUIN package version 3.5.2.2 (Excoffier and Lischer, 2010). The STRUCTURE software that include cluster techniques based on the Bayesian approach were used to analyze population structures (Pritchard et al., 2000; Falush et al., 2003, 2007; Hubisz et al., 2009). The population structure analysis was performed using independent allele frequencies and an admixture model (burn of 20.000, followed by $100.000 \mathrm{MCMC}$ iterations with 20 replicate runs for each cluster/ subpopulations number $(\mathrm{K})$.

The appropriate number of clusters was identified using $\Delta \mathrm{K}$ values that expressing the proportion of alteration in the logarithmic probability $\operatorname{Pr}(\mathrm{X} \mid \mathrm{K})$ of data between $\mathrm{K}$ values (from 2 to 7 ) according to a method $(\Delta \mathrm{K}=\mathrm{m}|\mathrm{L} "(\mathrm{~K})| / \mathrm{s}[\mathrm{L}(\mathrm{K})])$ reported by Evanno et al. (2005). The most suitable $K$ value was determined according to with $\Delta \mathrm{K}$ value calculated by the STRUCTURE harvester program (Earl and Vonholdt, 2012). The CLUMPAK program reported by Kopelman et al. (2015) was used to find the best alignment from the obtained STRUCTURE results.

\section{RESULTS}

In the present study a total 511 alleles were detected from eighteen microsatellites used to determine genetic diversity among breeds belonging to Algeria and Turkey. Molecular genetic polymorphism statistics obtained from the microsatellites used is given in Table 3.

The mean number of alleles $(\mathrm{Na})$ and effective number of alleles (Ne) were 28.39 and 15.32, respectively. The obtained PIC values were found to be between 0.89 (ILTS0019 and ILTS0087) and 0.96 (CSRD0247) with a mean PIC values of 0.93.Two microsatellites (SRCSRP0023 and OarFCB20) out of eighteen loci showed a negative $\mathrm{F}_{\text {IS }}$ values. The $\mathrm{F}_{\text {IT }}$ value, which represents general heterozygosity loss, was observed in the range from 0.037 (OARFCB20) to 0.301 (INRA063), and the mean of $F_{I T}$ values was 0.146.In this study the highest $\mathrm{F}_{\mathrm{ST}}$ was observed in CSRD0247 $(0.120)$, and the lowest FST in INRA0023 (0.033) with a mean of 0.069 . The highest and lowest observed heterozygosity (Ho) values were observed in OarFCB20 locus (0.91), and INRA063 locus (0.66), respectively. Mean value of $\mathrm{D}_{\mathrm{ST}}$ revealing the diversity between breeds, GST defining the coefficient of gene differentiation, and HT indicating Nei's gene diversity values were found as $0.051,0.054$ and 0.940 , respectively. The eighteen microsatellite loci used in the study were tested using the $\chi^{2}$ test in terms of compliance with Hardy-Weinberg equilibrium (HWE). The $\chi^{2}$ test findings demonstrated that the allele distributions of all microsatellite markers did not comply with the HardyWeinberg equilibrium. It is seen that all microsatellites have values below $20 \%$, which is the critical value for null allele frequency, when the null allele frequencies are examined. The results of genetic diversity for each breed are summarized in Table 4.

The MNA across the breeds ranged from 12.78 in the MO breed to 15.72 in the AR breed. The observed heterozygosity ranged from $0.77(\mathrm{HG})$ to $0.88(\mathrm{NK})$. All the studied breeds showed positive $F_{I S}$ values. A total of 117 private alleles were identified in the present study. Private allele numbers greater than $5 \%$ in $\mathrm{HG}, \mathrm{DA}, \mathrm{ME}$, $\mathrm{MO}, \mathrm{AR}$ and NK goat breeds were $6,16,8,8,6$ and 14 , respectively. Analysis of Molecular Variance (AMOVA), which is a method of determining population differentiation using molecular data, was used for detection of genetic variation between individuals and populations (Table 5). 
Table 3. Genetic polymorphism parameters of the eighteen investigated loci in Algerian and Turkish goat breeds.

\begin{tabular}{|c|c|c|c|c|c|c|c|c|c|c|c|c|c|c|c|}
\hline Loci & $\mathbf{N}$ & $\begin{array}{c}\text { Allelic } \\
\text { range } \\
\text { (bp) }\end{array}$ & $\mathbf{N a}$ & $\mathrm{Ne}$ & PIC & FIS $_{\text {IS }}^{*}$ & $\mathbf{F}_{\text {IT }}{ }^{*}$ & $\mathbf{F}_{\mathbf{S T}}{ }^{*}$ & Но & He & F(Null) & D $_{\text {ST }}$ & GsT & $\mathbf{H}_{\mathbf{T}}$ & HWE \\
\hline INRA0132 & 318 & $130-190$ & 29 & 14.20 & 0.93 & $0.048^{* *}$ & $0.081^{* * *}$ & $0.034^{* * *}$ & 0.86 & 0.93 & 0.038 & 0.024 & 0.026 & 0.941 & ${ }^{* * * *}$ \\
\hline HSC & 320 & $259-309$ & 27 & 18.11 & 0.94 & $0.069^{* * *}$ & $0.117^{* * *}$ & $0.052^{* * *}$ & 0.84 & 0.94 & 0.056 & 0.048 & 0.051 & 0.948 & $* * *$ \\
\hline BM1818 & 318 & $218-298$ & 30 & 16.20 & 0.94 & $0.117^{* * *}$ & $0.178^{* * *}$ & $0.070^{* * *}$ & 0.78 & 0.94 & 0.091 & 0.052 & 0.056 & 0.941 & $* * *$ \\
\hline BM1329 & 319 & $107-190$ & 22 & 11.32 & 0.91 & $0.152^{* * *}$ & $0.219^{* * *}$ & $0.080^{* * *}$ & 0.72 & 0.91 & 0.113 & 0.061 & 0.066 & 0.924 & $* * *$ \\
\hline SRCSRP0023 & 317 & $81-133$ & 27 & 14.03 & 0.93 & $-0.005^{\mathrm{ns}}$ & $0.100^{* * *}$ & $0.104^{* * *}$ & 0.85 & 0.93 & 0.040 & 0.08 & 0.085 & 0.938 & *** \\
\hline OarFCB20 & 319 & $73-129$ & 29 & 14.14 & 0.93 & $-0.023^{\mathrm{ns}}$ & $0.037^{\mathrm{ns}}$ & $0.059^{* * *}$ & 0.91 & 0.93 & 0.012 & 0.041 & 0.044 & 0.934 & $* * *$ \\
\hline SRCSRP005 & 319 & $148-208$ & 27 & 16.48 & 0.94 & $0.088^{* * *}$ & $0.144^{* * *}$ & $0.061^{* * *}$ & 0.82 & 0.94 & 0.070 & 0.052 & 0.055 & 0.946 & *** \\
\hline McM0527 & 319 & $147-213$ & 30 & 16.88 & 0.94 & $0.112^{* * *}$ & $0.185^{* * *}$ & $0.082^{* * *}$ & 0.78 & 0.94 & 0.094 & 0.063 & 0.066 & 0.95 & $* * *$ \\
\hline CSRD0247 & 319 & $96-243$ & 43 & 28.75 & 0.96 & $0.054^{*}$ & $0.167^{* * *}$ & $0.120^{* * *}$ & 0.82 & 0.97 & 0.079 & 0.099 & 0.102 & 0.965 & $* * *$ \\
\hline INRA0023 & 320 & $189-247$ & 28 & 15.47 & 0.93 & $0.027 \mathrm{~ns}$ & $0.059^{* *}$ & $0.033^{* * *}$ & 0.89 & 0.94 & 0.026 & 0.024 & 0.025 & 0.94 & $* * *$ \\
\hline INRA005 & 320 & $120-203$ & 38 & 13.36 & 0.92 & $0.179^{* * *}$ & $0.271^{* * *}$ & $0.113^{* * *}$ & 0.69 & 0.93 & 0.151 & 0.072 & 0.076 & 0.944 & ${ }^{* * *}$ \\
\hline ILTS0087 & 320 & $127-162$ & 18 & 9.98 & 0.89 & $0.081^{* * *}$ & $0.124^{* * *}$ & $0.047^{* * *}$ & 0.80 & 0.90 & 0.060 & 0.033 & 0.037 & 0.91 & $* * *$ \\
\hline ILTS0019 & 319 & $124-170$ & 21 & 9.74 & 0.89 & $0.100^{* * *}$ & $0.147^{* * *}$ & $0.052^{* * *}$ & 0.77 & 0.90 & 0.076 & 0.034 & 0.037 & 0.912 & *** \\
\hline INRA063 & 318 & $141-217$ & 35 & 14.46 & 0.93 & $0.231^{* * *}$ & $0.301^{* * *}$ & $0.092^{* * *}$ & 0.66 & 0.93 & 0.171 & 0.061 & 0.064 & 0.95 & $* * *$ \\
\hline BM1258 & 318 & $94-139$ & 21 & 15.53 & 0.93 & $0.063^{* * *}$ & $0.101^{* * *}$ & $0.041^{* * *}$ & 0.85 & 0.94 & 0.049 & 0.033 & 0.035 & 0.941 & *** \\
\hline SRCRSP0024 & 317 & $129-187$ & 30 & 16.25 & 0.94 & $0.106^{* * *}$ & $0.166^{* * *}$ & $0.068^{* * *}$ & 0.79 & 0.94 & 0.085 & 0.047 & 0.049 & 0.949 & $* * *$ \\
\hline SRCRSP0008 & 318 & $201-259$ & 25 & 17.36 & 0.94 & $0.037^{*}$ & $0.086^{* * *}$ & $0.052^{* * *}$ & 0.87 & 0.94 & 0.040 & 0.035 & 0.036 & 0.952 & $* * *$ \\
\hline MAF0065 & 316 & $105-205$ & 31 & 13.59 & 0.92 & $0.071^{* * *}$ & $0.140^{* * *}$ & $0.074^{* * *}$ & 0.81 & 0.93 & 0.067 & 0.065 & 0.07 & 0.928 & $* * *$ \\
\hline Mean & & & 28.39 & 15.32 & 0.93 & 0.083 & 0.146 & 0.069 & 0.81 & 0.93 & 0,073 & 0.051 & 0.054 & 0.940 & \\
\hline
\end{tabular}

Table4. Genetic polymorphism parameters according to studied goat breeds across 18 loci.

\begin{tabular}{|c|c|c|c|c|c|c|c|c|}
\hline \multirow{2}{*}{ Breeds } & \multirow{2}{*}{ MNA } & \multicolumn{2}{|c|}{ Mean Heterozigosity } & \multirow{2}{*}{ Fis } & \multirow{2}{*}{ HWE } & \multicolumn{3}{|c|}{ NPA } \\
\hline & & Ho (SE) & He (SE) & & & Freq. $\geq 5 \%$ & Freq. $<\% 5$ & Total \\
\hline $\mathrm{HG}$ & 14.33 & $0.78(0.035)$ & $0.84(0.014)$ & $0.075^{* * *}$ & 9 & 6 & 12 & 18 \\
\hline DA & 14.89 & $0.77(0.028)$ & $0.88(0.006)$ & $0.136^{* * *}$ & 13 & 16 & 17 & 33 \\
\hline ME & 13.94 & $0.82(0.029)$ & $0.89(0.010)$ & $0.077^{* * *}$ & 15 & 8 & 7 & 15 \\
\hline MO & 12.78 & $0.82(0.024)$ & $0.88(0.009)$ & $0.074^{* * *}$ & 4 & 8 & 3 & 11 \\
\hline $\mathrm{AR}$ & 15.72 & $0.80(0.016)$ & $0.89(0.007)$ & $0.106^{* * *}$ & 14 & 6 & 14 & 20 \\
\hline NK & 15.67 & $0.88(0.012)$ & $0.90(0.006)$ & $0.018^{\mathrm{ns}}$ & 13 & 14 & 6 & 20 \\
\hline
\end{tabular}

MNA: Mean number of alleles, Ho: mean observed heterozygosity, He: mean expected heterozygosity, Fis: within-breed heterozygote deficiency, HWE: number of loci not in the Hardy-Weinberg equilibrium $(\mathrm{P}<0.05)$, NPA: number of private alleles

Table 5.Results for analysis molecular variance (AMOVA) revealing the distribution of genetic diversity.

\begin{tabular}{lccccc}
\hline Variation Sources & DF & SS & VC & PV (\%) & FI \\
\hline Among population & 5 & 340.82 & $0.5796 \mathrm{Va}$ & 6.87 & $\mathrm{~F}_{\text {IS }}=0.079$ \\
Among individuals within populations & 314 & 2659.21 & $0.6180 \mathrm{Vb}$ & 7.33 & $\mathrm{~F}_{\mathrm{ST}}=0.069$ \\
Within individuals & 320 & 2314.50 & $7.2328 \mathrm{Vc}$ & 85.79 & $\mathrm{~F}_{\text {IT }}=0.142$ \\
\hline Total & $\mathbf{6 3 9}$ & $\mathbf{5 3 1 4 . 5 3}$ & $\mathbf{8 . 4 3 0 4}$ & &
\end{tabular}

DF: degree of freedom, SS: sum of square, VC: variance components, PV: percentage of variance, FI: fixation index

It was revealed $85.79 \%$ of the total variance was found within individuals while $7.33 \%$ among individuals within populations and $6.87 \%$ among population. The $\mathrm{F}_{\mathrm{ST}}$ value obtained from the AMOVA analysis was similar to the $\mathrm{G}_{\mathrm{ST}}$ value. This suggests that existing genetic diversity can be explained by genetic differences between individuals. The phylogenetic tree based on Nei's Da (Nei et al., 1983) distance matrix belong to breeds studied was given in Figure 1.

The dendrogram revealed three clusters (Figure 1). The first cluster was consisted by HG and DA goat breeds raised in Turkey, the second cluster was formed by ME, MO and AR goat breeds and the third cluster was formed by NK goat breed sampled from Algeria. 
The number of subpopulations $(\mathrm{K})$ in the overall of the analyzed samples was assessed by Bayesian approach implemented by STRUCTURE. Population structure analysis result which is containing clustering number $(\mathrm{K}=2$ to 6 ) was given in Figure 2. Obtained results that include clustering number and estimates of posterior probabilities $([\operatorname{LnPr}(\mathrm{X} \mid \mathrm{K})]$ for $\Delta \mathrm{K}$ values were given in Table 6.

The contribution of the Algerian and Turkish breed was clearly demonstrated with STRUCTURE analysis However, it was interesting that two different native Turkish breeds, HG and DA, cannot be differentiated and show high genetic similarity, and this should be investigated further. It was understood from the dendrogram and the STRUCTURE analysis that the MO and AR breeds were in the same group. The results of the structure analysis show a high level of breed admixture.

These finding has resulted in a suitable group number of 3 in STRUCTURE analysis. It is seen that the optimal number of groups was 3 considering the value of $\Delta K$ obtained by the method reported by Evanno et al. (2005).

Table 6. Estimated posterior probabilities $[\mathrm{LnPr}$ $(\mathrm{X} \mid \mathrm{K})]$ for different numbers of inferred clusters $(K)$ and $\Delta K$ statistics.

\begin{tabular}{ccc}
\hline $\mathbf{K}$ & {$[\mathbf{L n} \operatorname{Pr}(\mathbf{X} \mid \mathbf{K})]$} & $\Delta \mathbf{K}$ \\
\hline 2 & $-31861,050$ & - \\
$\mathbf{3}$ & $\mathbf{- 3 0 6 4 1 , 8 9 0}$ & $\mathbf{2 , 8 6 9 8}$ \\
4 & $-29657,270$ & 1,8162 \\
5 & $-28798,175$ & 2,7896 \\
6 & $-28305,990$ & 1,8030 \\
\hline
\end{tabular}

0,167

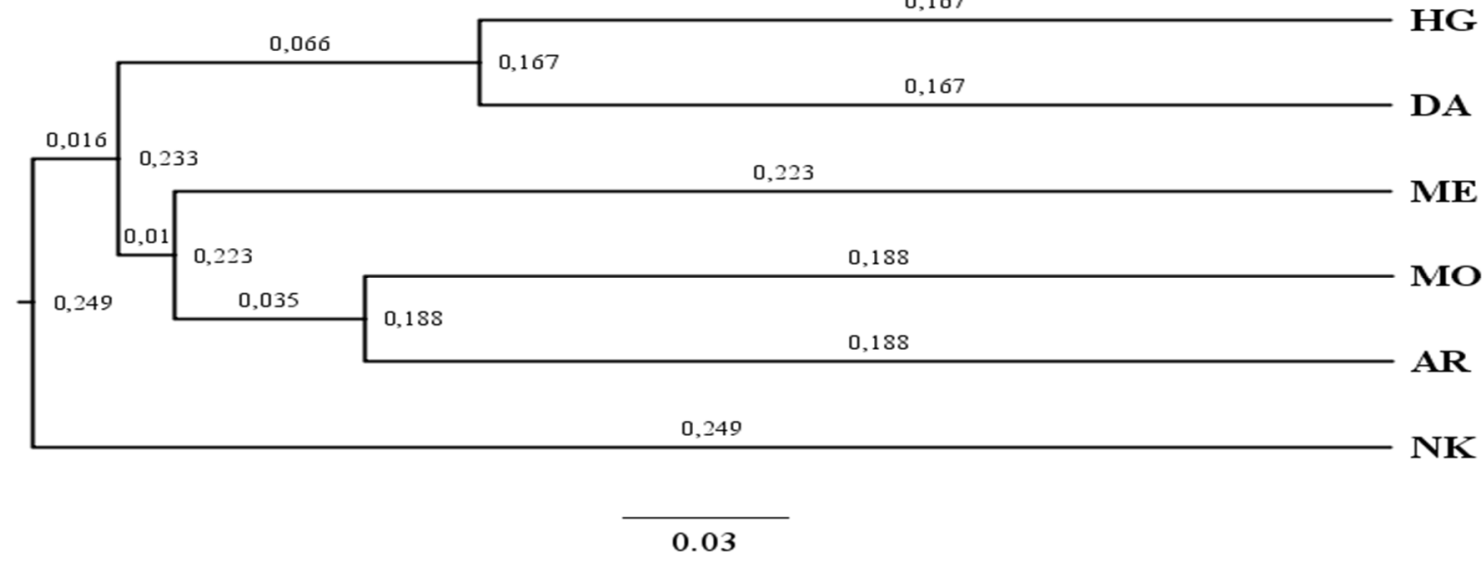

Figure1. Dendrogram based on Nei's Da (Nei 1983) distance matrix in HG, DA, ME, MO, AR and NK goat breeds (bootstrap resampling methodology (1000 replicates).

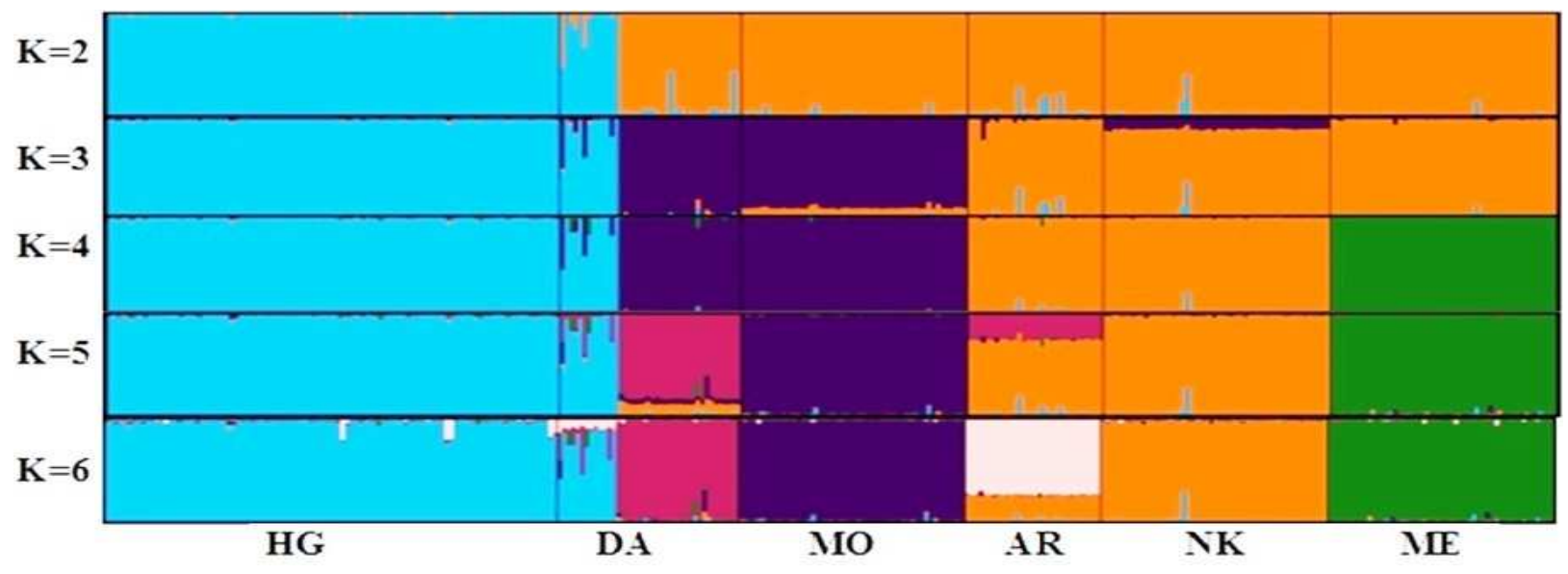

Figure2. CLUMPAK plot of STRUCTURE assignment results (K=2 to 6)

\section{DISCUSSION}

The panel of selected microsatellites showed good performances in diversity studies according to the number of detected alleles, gene diversity, PIC and $F_{\text {IS }}$ values. These obtained values indicated that the microsatellite markers used show high genetic polymorphism for the studied breeds. A total of 511 
alleles from 18 microsatellites loci were observed. Na and $\mathrm{Ne}$ observed in the present study were higher than values obtained from the other goat breeds (Missohou et al., 2011; Parejo et al., 2015; Singh et al., 2015; Bosman et al., 2015; Dominguez et al., 2018). It can be said that the studied breeds have a high genetic diversity according to these results when considering literature is evaluated. The statistical evaluation of informativeness of a markers is defined by PIC values and the genetic markers that showing PIC values higher than 0.5 are normally considered as informative in population genetic analysis (Botstein et al., 1980). The present PIC values were well than PIC values found by Agaoglu and Ertugrul, (2012) and Parejo et al. (2015), Singh et al. (2015) and Bosman et al., (2015). The PIC values estimated in the present study was above 0.91 , the selected markers proved to be highly informative for analysing genetic diversity within and between populations as reported in Radhika et al., (2015). This may be due to the fact that there was increased level of heterozygosity and allele richness in the population which are the good indicators of genetic polymorphism in present study on Algerian and Turkish goats. These values are indicative of the fact that the markers used were highly informative for analysis of genetic diversity. $F_{I S}$ is a measure of the deviation of genotypic frequencies from panmictic frequencies in terms of heterozygous deficiency or excess. Negative $F_{I S}$ values indicate heterozygote excess and positive values indicate heterozygote deficiency compared with HardyWeinberg equilibrium expectations (Hedrick, 2000).

Only Two loci showed a negative $\mathrm{F}_{\text {IS }}$ values and indicating excess of heterozygotes. Parejo et al. (2015) reported that 13 loci showed negative $\mathrm{F}_{\text {IS }}$ values. The $\mathrm{F}_{\text {IS }}$ and $F_{\text {IT }}$ values in present study were higher than results of Agaoglu and Ertugrul (2012), Bosman et al. (2015), Parejo et al. (2015) and Dominguez et al. (2018). In this study the mean of $\mathrm{F}_{\text {ST }}$ was 0.069 indicating that only 6.9 $\%$ of genetic variability could be attributed to difference between breeds, whereas $93.1 \%$ of genetic differentiation was due to differences among individuals within the breed. Our result is similar to $7 \%$ in 45 goat breeds from Europe and Middle East analyzed by Canon et al., (2006), 7.2\% by Parejo et al. (2015). The He value that higher than Ho value, indicating heterozygote deficit in the population. Though Ho (0.81) was lower than $\mathrm{He}$ (0.93), the overall mean value for Ho obtained in the present study was comparatively higher than the reports of Agaoglu and Ertugrul (2012), Singh et al. (2015). Thus it can be concluded from the result that genetic diversity of the populations studied was high, but with slight heterozygote deficit as evidenced by slightly lower Ho values. Higher genetic variation may be attributed to intermixing of different populations and lower selection pressure also reported by Radhika et al., (2015) and Singh et al., (2015), whereas heterozygote deficit may be due to inbreeding caused by lack of sufficient number of good breeding bucks in the population (Radhika et al., 2015, Tefiel et al 2018), large population size and immigration of new genetic materials (Singh et al., 2015, Tefiel et al 2018). When the HWE assumptions are violated in a population, there is deviation of genotype frequencies. The deviations observed in some markers in populations may have been caused by inbreeding, by the non-amplification (presence of null alleles), by group defective alleles or selection against heterozygous.

The mean number of alleles (MNA), and observed heterozygosity across the breeds were compared well with Agaoglu and Ertugrul (2012), Bosman et al. (2015). In most of the populations, expected heterozygosity is higher than the observed heterozygosity indicating heterozygosity deficiency. All the studied breeds showed positive $F_{\text {IS }}$ value compared well than Bosman et al. (2015). This study shows that there is a high genetic differentiation in the Algerian and Turkish goat breeds. The frequency of private alleles was high in comparison to the frequency of the private alleles identified for the Swiss Toggenburg (11\%) by GlowatzkiMullis et al., (2008) and only four alleles at a frequency higher than 1\% (Bosman et al., 2015). A private allele is considered to have a high frequency if it occurs in more than $20 \%$ of the population (Glowatzki-Mullis et al., 2008). HWE deviations have been reported in various studies and indicate deviation from random mating (Barker et al., 2001). Agaoglu and Ertugrul (2012) reported that all the Turkish goat breeds were in the Hardy-Weinberg equilibrium. A total of 3 clusters were counted in our dendrogram, it indicated that Algerian and Turkish goat breeds are classified in different clusters and clearly was genetically distinct. In the present work, the dendrogram indicated the genetically closer goat breeds were clustered together forming one separated clade as HG and DA in the Turkish breeds and MO, ME and AR in the Algerian breeds. The NK goat breed was clustered separately from the other breeds and clearly was genetically distinct. In the Table $6, \Delta \mathrm{K}$ value indicated that the most suitable group number was $3(\mathrm{~K}=3)$. The obtained results from population structure analysis revealed that breeds studied are completely separated and shown no genetic admixture. It seen that population structure analysis result was in agreement with dendrogram.

Conclusion: We used microsatellite markers to carry out the first genetic study including four Algerian and two Turkish goat breeds. All the approaches used showed that the Algerian and Turkish breeds present an important level of genetic diversity. Our results showed that breeds studied have a robust structure, revealing a clear differentiation between the Algerian and Turkish goat breeds. Further studies are recommended considering goats from other Mediterranean countries. 
Acknowledgments: We acknowledge Adnan Menderes University Agricultural Biotechnology and Food Safety Application and Research Center (ADUTARBIYOMER) for providing laboratory facilities for all the molecular genetics analyses. The authors wish to thank the Algerian and Turkish goat breeders for their collaboration.

\section{REFERENCES}

Agaoglu, O.K., O. Ertugrul (2012). Assessment of genetic diversity, genetic relationship and bottleneck using microsatellites in some native Turkish goat breeds. Small Ruminant Res. 105, 53-60.

Ajmone-Marsan, P., Colli, L., Han, J.L., Achilli, A., Lancioni, H., Joost, S., Crepaldi, P., Pilla, F., Stella, A., Taberlet, P., Boettcher, P., Negrini, R., Lenstra, J.A., Italian Goat Consortium, G., Econogene Consortium, Globaldiv Consortium (2014). The characterization of goat genetic diversity: towards a genomic approach. Small Ruminant Res.121, 58-72.

Amills, M., Capote, J., G. Tosser-Klopp (2017). Goat domestication and breeding: a jigsaw of historical, biological and molecular data with missing pieces. Animal Genetics. 48, 631-644.

Barker, J.S.F., Tan, S.G., Moore, S.S., Mukherjee, T.K., Matheson, J.L., O.S. Selvaraj (2001).Genetic variation within and relationships among populations of Asian goats(Capra hircus). J. Anim. Breed. Genet. 118, 213-233.

Belantar, I., Tefiel, H., S.B.S. Gaouar (2018) .Phenotypic characterization of local goat population in western Algeria (Wilaya of Relizane) with morphometric measurements and milk analysis. Genetic Biodiv J. 2, 55-66.

Bosman, L., Van Marie-Koster, E., C. Visser(2015). Genetic diversity of South African dairy goats for genetic management and improvement. Small Ruminant Res. 123,224-231.

Botstein, D., White, R.L., Skolnick, M., R.W. Davis (1980). Construction of a genetic linkage map in man using restriction fragment length polymorphisms. Am. J. Hum. Genet. 32, 314331.

Canon, J., Garcia, D., Garcia-Atance, M.A., Obexer-Ruff, G., Lenstra, J.A., Ajmone-Marsan, P., S. Dunner(2006). Geographical partitioning of goat diversity in Europe and the Middle East. Ani. Genetic. 37 (4): 327-334.

Darcan, N.K., N. Silanikove(2018). The advantages of goats for future adaptation to Climate Change: A conceptual overview. Small Ruminant Res.163, 34-38.

Domínguez, M. A., Pérez de la Rosa, J.D., Landi, V., Pérez de la Rosa, J., Vazquez, N., Martínez, A. M., G.
Fuentes-Mascorro(2018).Genetic diversity and population structure analysis of the Mexican Pastoreña Goat. Small Ruminant Res.168, 76-81. https://doi.org/10.1016/j.smallrumres.2018.09.019

Earl, D.A., B.M. Vonholdt(2012). STRUCTURE HARVESTER: a website and program for visualizing STRUCTURE output and implementing the Evanno method. Conserv.Genet. Res. 4, 359-361.

Evanno, G., Regnaut, S., J. Goudet (2005). Detecting the number of clusters of individuals using the software STRUCTURE: a simulation study. Mol. Ecol. 14, 2611-2620.

Excoffier, L., H.E.L. Lischer (2010). Arlequin suite ver 3.5: a new series of programs to perform population genetics analyses under Linux and Windows. Mol. Ecol. Res. 10, 564-567.

Falush, D., Stephens, M., J.K. Pritchard (2003). Inference of population structure using multilocus genotype data: linked loci and correlated allele frequencies. Genetics. 164, 1567-1587.

Falush, D., Stephens, M., J.K. Pritchard (2007). Inference of population structure using multilocus genotype data: dominant markers and null alleles. Mol. Ecol. Notes. 7, 574-578.

Fantazi, K., Tolone, M., Amato, B., Sahraoui, H., Vincenzo di Marco, L.P., La Giglia, M., Gaouar, S.B.S., M. Vitale(2017). Characterization of morphological traits in Algerian indigenous goats by multivariate analysis. Genetic. Biodiv. J. 1, 20-30.

FAO. (2011).Molecular genetic characterization of animal genetic resources.FAO Animal Production and Health Guidelines 9 Food and Agriculture Organization, Rome, Italy.

FAO. (2016).FAOSTAT data ,http://www.fao.org/faostat/en/\#data

Glowatzki-Mullis, M.L., Muntwyler, J., Baumle, E., C. Gaillard (2008). Genetic diversity measures of Swiss goat breeds as decision-making support for conservation policy.Small Ruminant Res. 74, 202-211.

Goudet, J. (2001). FSTAT; a Program to Estimate and Test Gene Diversities and Fixation Indices Version 2 9.3. http://www.unil.ch/izea/softwares/fstat.html.

Gurler, S., F. Bozkaya (2013). Genetic diversity of three native goat populations raised inthe south-Eastern region of Turkey. Kafkas Univ Vet Fak. 19, 207213.

Gursoy, O. (2006). Economics and profitability of sheep and goat production in Turkey under new support regimes and market conditions. Small Ruminant Res.62, 181-191.

Hedrick, P.W. (2000). Genetics of Population. Jones and Bartlett, Sudbury. Mass. 34-47. 
Hubisz, M.J., Falush, D., Stephens, M., J.K. Pritchard (2009). Inferring weak population structure with the assistance of sample group information. Mol Ecol Resour. 9,1322-1332.

Kalinowski, S.T., Taper, M.L., T.C. Marshall (2007). Revising how the computer program CERVUS accommodates genotyping error increases success in paternity assignment.Mol Ecol. 16, 1099-1106.

Keskin, M. (2000). Determination of some morphological characteristics and performance of Shami (Damascus) goats in extensive breeding condition of Hatay region. PhD, Thesis. Inst. of Nat App Sc., Must. K. Univ.,, Hatay, Turkey.

Keskin, M., O. Biçer (1997). Some morphological and physiological characteristics of goat breeds in Hatay region. Mustafa Kemal Univ. J. of Agr. Fac.. 2, 73-86.

Kopelman, N.M., Mayzel, J., Jakobsson, M., Rosenberg, N.A., I. Mayrose (2015).Clumpak: a program for identifying clustering modes and packaging population structure inferences across K. Mol Ecol Res .15, 1179-1191.

Langella, O (1999). Populations 1.2.31.Population Genetic Software (Individuals or Populations Distances, Phylogenetic Trees). (Acces date: 09 July 2015).

Luikart, G., Gielly, L., Excoffier, L., Vigne, J.D., Bouvet, J., P. Taberlet (2001). Multiple maternal origins and weak phylogeographic structure in domestic goats. P. Natl. Acad. Sci. USA. 98, 5927-5932.

Marshall, T.C., Slate, J., Kruuk, L.E.B., J.M. Pemberton (1998). Statistical confidence for likelihood-based paternity inference in natural populations. Mol. Ecol. 7, 639-655.

Martin, B.G. (1974). Arab migrations to East Africa in medieval times. Int. J. Afr. Hist. Stud. 7, 367390.

Miller, S.A., Dykes, D.D., H.F. Polesky (1988). A simple salting out procedure for extracting DNA from human nucleated cells. Nuc. Acids Res. 16, 12151215.

Missohou, A., Poutya, M.R., Nenonene, A., Dayo, G.K., Ayssiwede, S.B., Talaki, E., Issa, Y., A. Fane (2011). Genetic diversity and differentiation in nine West African local goat breeds assessed via microsatellite polymorphism. Small Ruminant Res. 99, 20-24.

Montgomery, G.W., J.A. Sise (1990). Extraction of DNA from Sheep white blood-cells. New Zeal. J. Agr. Res. 33, 437-441.

Nei, M., Tajima, F., Y. Tateno (1983). Accuracy of Estimated Phylogenetic Trees from MolecularData .2. Gene-Frequency Data. J. Mol. Ev. 19, 153-170.

Parejo, J.C., Padilla, J.A., Calero, R., Martinez-Trancon, M., Sansinforiano, E., Rabasco, A., Salazar, J.,
J.A. Bravo (2015).Population genetic structure and conservation management of Retinta Extremena goats. Small Ruminant Res. 124, 916.

Peakall, R., P.E. Smouse (2006). GenAlEx 6: genetic analysis in Excel: population genetic software for teaching and research. Mol Ecol Notes. 6, 288295.

Peakall, R., P.E. Smouse (2012). GenAlEx 6.5: genetic analysis in Excel. Population genetic software for teaching and research-an update. Bioinformatics. 28, 2537-2539.

Porter, V (2002). Mason's world dictionary of livestock breeds, types and varieties. 5th ed. CABI International Publishers. Oxfordshire, (UK). $1021 \mathrm{p}$

Pritchard, J.K., Stephens, M., P. Donnelly (2000).Inference of population structure using multilocus genotype data. Genetics. 155, 945-959.

Radhika, G., Raghavan, K.C., Aravindakshan, T.V., V. Thirupathy (2015). Genetic diversity and population structure analysis of native and crossbred goat genetic groups of Kerala, India. Small Ruminant Res. 131, 50-57.

Rambaut, A., A. Drummond (2015). FigTree, ver. 1.4.2. Available: http:/tree.bio.ed.ac.uk/software/figtree/ Accessed date: 09.07.2015.

Raymond, M., F. Rousset (2011). GENEPOP version 4.0. 10.

Singh, G., Thakur, Y., Kour, A., Sankhyan, V., S. Katoch (2015). Genetic characterizationof Gaddi goat breed of Western Himalayas using microsatellite markers. Vet. World. 8, 527-531.

Taberlet, P., Coissac, E., Pansu, J., F. Pompanon (2011). Conservation genetics of cattle, sheep, and goats. Cr. Biol. 334, 247-254.

Tefiel, H., Ata, N., Chahbar, M., Benyarou, M., Fantazi, K., Yilmaz, O., Cemal, I., Karaca, O., Boudouma, D., S.B.S. Gaouar (2018). Genetic characterization of four Algerian goat breeds assessed by microsatellite markers. Small Ruminant Res. 160, 65-71.

https://doi.org/10.1016/j.smallrumres.2018.01.021

Weir, B.S., C.C. Cockerham (1984).Estimating F-Statistics for the Analysis of Population-Structure. Evolution. 38, 1358-1370.

Wright, S. (1931). Evolution in mendelian populations. Genetics. 16, 97-159.

Yilmaz, O., Kor, A., Ertugrul, M., R.T. Wilson (2012). The domestic livestock resources of Turkey: goat breeds and types and their conservation status. Ani. Genetic Res.105-116.

Zeder, M.A., B. Hesse (2000). The initial domestication of goats (Capra hircus) in the Zagros mountains 10,000 years ago. Science. 287, 2254-2257. 